\title{
Developing a senior project management capstone course for information systems and technology majors
}

\author{
Renel Smith, University of the Virgin Islands, renel.smith@uvi.edu
}

\begin{abstract}
Businesses value soft skills, such as leadership, problem-solving, teamwork and communication, in Information Systems/Information Technology (IS/IT) professionals. A capstone course is one method of providing a safe environment for students to develop both their hard and soft skills while gaining practical experience working on real-world problems. This paper documents the establishment of a project management capstone course for Information Systems and Technology (IST) students in their senior year of college. It reflects on how the integration of real-world projects allows students to apply their knowledge of systems analysis and design, requirements gathering and project management, while at the same time developing critical soft skills in an active learning environment. It discusses partnering with industry to provide students with an experiential learning culture with the goal of producing well-rounded industry professionals.
\end{abstract}

Keywords: Information Systems (IS), Information Technology (IT), Project Management (PM), Soft Skills and IS Curriculum

\section{Introduction}

Project management (PM) is one of the top five skills desired by companies hiring entry-level Information Systems / Information Technology (IS/IT) employees (Leonard et al., 2019). It is considered an important component of the Information Systems (IS) core because it is essential for success in all organizational endeavors, especially for projects involving IS/IT (Longenecker et al., 2015). Nonetheless, PM skills are critically lacking in many IS/IT organizations (Crawford, 2006; Schwalbe, 2019). To be professionally successful, IS/IT students should have sound training in PM principles, as well as opportunities to apply those skills to real-world problems. Furthermore, since projects involve working with people, PM training also helps to develop those soft skills that are a key requirement for success in project settings. Such soft skills include communication, teamwork, time management, and situational intelligence, which are all valued by employers hiring young professionals (Marques, 2013).

Many universities have programs that require final senior projects or capstone courses (Konrad et al., 2018). At our university, the University of the Virgin Islands, we developed a project management capstone course as part of our Information Systems and Technology (IST) curriculum. Designed with support from local businesses, this course allows students to apply project management principles they learned in a prior course to solve real-world business problems. Successfully implementing the course creates a win-win-win experience for everyone:

1. Businesses involved receive a useful product or service. 


\section{Issues in Information Systems}

Volume 22, Issue 3, pp. 14-25, 2021

2. Students gain valuable real-world experience while developing their professional skills, both of which greatly enhance their appeal to potential employers.

3. Our university successfully partners with industry to provide students with an experiential learning culture that promotes the development of well-rounded IS/IT professionals.

The first part of the paper describes the background and need for a PM capstone course to be included in the core IS/IT curriculum. The second part of the paper describes the framework of the PM capstone course that was developed for our university's IST program and summarizes the perceived benefits of the course. The paper ends with a conclusion and the identification of opportunities for future work in this area.

\section{Background}

\section{Project Management Curriculum}

Curriculum models can be helpful in providing guidance and affording institutions the ability to utilize local resources and satisfy local requirements and conditions. Curriculum models, however, are merely guidelines, and each institution must apply the model to fit its respective program. Many schools build their IS curriculum using input from the model curriculum for information systems programs. A review of the most recent IS curriculum models indicates that project management is a key skill set (Leidig, et al., 2020; Topi et al., 2010).

Model curricula for the IS discipline usually include a basic Project Management course (Bohler et al., 2020). PM courses generally cover technical and managerial concepts. Students are exposed to all aspects of PM such as scoping, scheduling, budgeting and managing resources. Since it is not unusual for project managers to manage resources outside their chain of command, PM courses also teach students softer skills such as motivation, teamwork, interpersonal communication and leadership.

The PM course within the IS curriculum is typically a standalone course. If it is not, basic PM concepts are included as a subset of a broader course in a student's program of study (i.e., PM concepts are sometimes covered in System Analysis and Design and/or Information Systems courses). The goal is to introduce students to the processes, methods, techniques and tools that organizations use to manage their information systems projects. As organizations undertake larger and more complex IS projects, PM capability is recognized as an essential ingredient in project success.

PM course content may be influenced by internationally recognized project management frameworks such as the Project Management Professional (PMP) certification offered by the Project Management Institute (PMI) (Task Force on PM Curricula, 2015) or the Projects IN Controlled Environments (PRINCE2) certification that was developed by the UK as a standard for government projects (mostly IS projects). Since PMI's best practices were used to implement the PM course and capstone content described in this paper, we focus only on PMI. PMI is a nonprofit professional membership association for project management professionals. PMI has established a recognized set of best practices, known as the Project Management Body of Knowledge (PMBOK), that can improve the chance of success of projects. PMBOK covers the five PM process groups and the ten knowledge areas common in most projects and serves as the basis of PM certification. In response to requests from the academic community, PMI has developed undergraduate PM curriculum guidelines (Project Management Institute, 2017). 


\section{Issues in Information Systems}

Volume 22, Issue 3, pp. 14-25, 2021

The capstone course is typically the last class in a program of study (Tabatabaei et al., 2005). The IS capstone class usually incorporates additional program requirements related to soft skills, but the course essentially covers the project management of a system's life cycle. Capstone courses help students develop the knowledge and skills required in the workplace (Dunlap, 2005). The concept of a capstone-type experience has gained wide support in academia, particularly in the engineering and information technology disciplines. Additionally, the experience gained from a capstone project can be added to a student's career portfolio.

A review of the project management and IS curriculum literature shows that there is a need for IS professionals with strong project management skills. A PM capstone course not only helps to address that need, but it is an important pedagogical tool that leverages real-world projects to reinforce classroom learning.

\section{Importance of Soft Skills}

Soft skills are the non-technical skills, sometimes referred to as "people skills," that are often overlooked in the management of projects. They are those capabilities, such as social skills, communication skills, social intelligence and emotional intelligence, that allow people to engage with others to effectively control and navigate their environment. Unlike technical skills, soft skills generally are not taught. Technical or "hard" skills refer to the technical knowledge required within a domain (Sukhoo et al., 2005). Examples of hard skills that are taught in IS programs are Computer Programming, Systems Analysis and Design, and Project Management.

Soft skills complement technical job skills (Matturro et al., 2019). A leading expert in the fields of communication and people skills reported that 80 percent of individuals who fail at work do not fail due to their lack of technical skills but rather because of their inability to relate well with others (Bolton, 1986). Classic soft skills can include negotiating, motivating, influencing, trust-building, conflict

management, problem-solving, communication, critical thinking, ethics, and leadership. These skills are essential to the success of a project manager. 


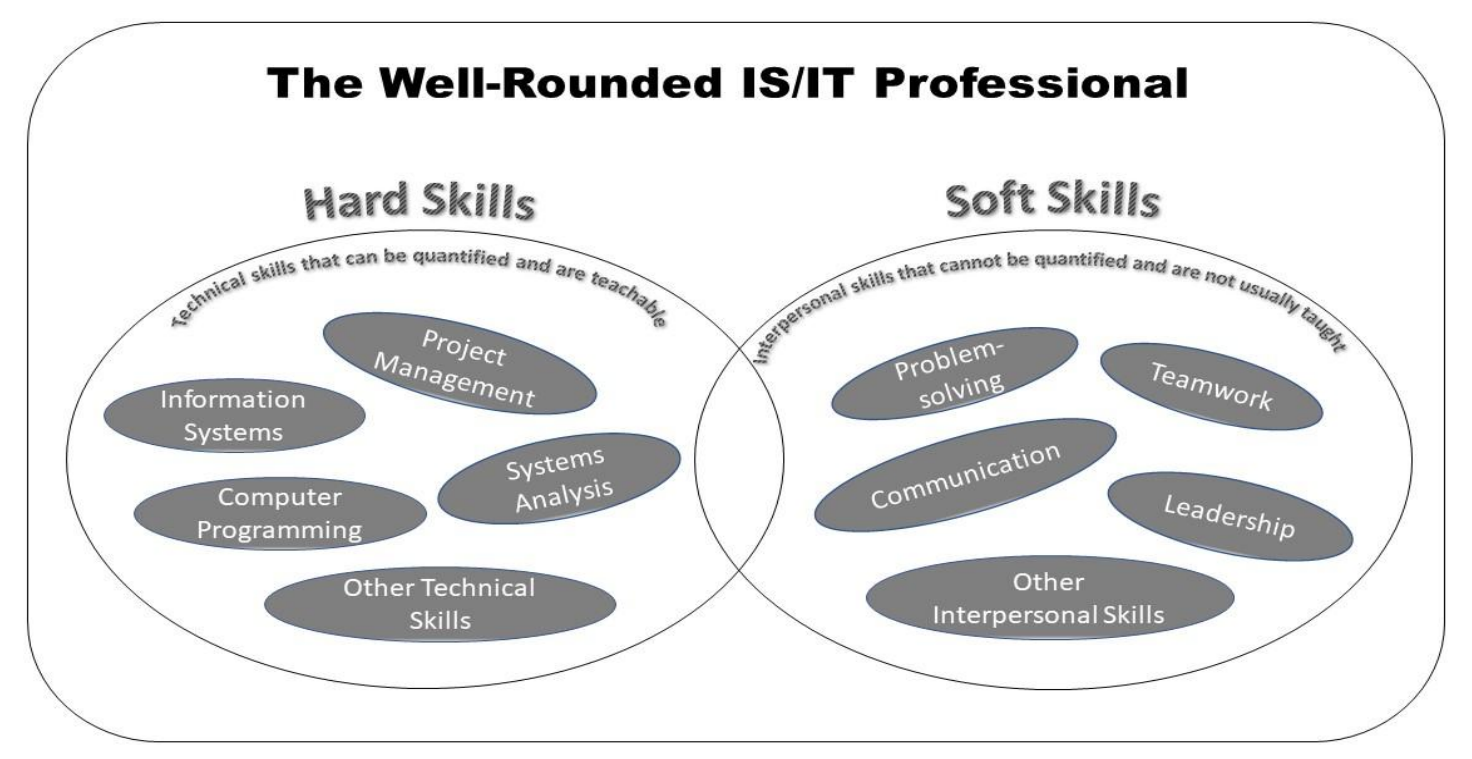

Figure 1: The Well-Rounded IS/IT Professional

In recent surveys that asked employers which attributes they most value, employers indicated the following soft skills: problem-solving, teamwork, communication, and leadership (NACE, 2020; Gray, 2021). These are all skills that are important for students' professional growth and development during and after college (Schulz, 2008).

1. Problem-solving Skills: Without the crucial skill of problem-solving, an employee's contribution to an organization is limited. Problems present an opportunity to add value to an organization and its customers. Projects face issues and risks that can impact their scope, schedule or budget. Problemsolving skills are required to navigate those issues and risks as they arise to keep the project on track.

2. Teamwork Skills: Companies do not want employees who work in silos. They want information technology professionals who are able to work well with others from various backgrounds and fields, such as sales, engineering, marketing, and customer service. People in non-IS/IT roles think differently than IS/IT professionals. Since project managers usually need to collaborate with other members of the organization who are not part of the project team, it is essential that they respect and embrace the different dynamics that occur in the workplace.

3. Leadership Skills: Leadership is the ability to influence or guide others to accomplish tasks or goals. Leadership skills are essential for the project manager, who needs to motivate and inspire teams. Leaders must have the ability to set strategy, inspire trust and motivate those around them (Kumar, 2009). As the person considered to be the hub of the team, a project manager must be able to lead.

4. Communication Skills: Communication skills refer to the ability to convey information and ideas effectively. Since project managers must be advocates for the project, they must be able to effectively communicate the goals and benefits to all stakeholders. Additionally, they must be able to effectively communicate project progress in formal reports as well as in presentations to senior management. Industry managers agree that good communication skills are a requirement when hiring a new college graduate into an IT position (NACE, 2020).

As the literature suggests, soft skills allow IS/IT professionals to perform better in the workplace, complementing the technical skills required to do their jobs (Troukens, 2013). Developing these skills in 


\section{Issues in Information Systems}

Volume 22, Issue 3, pp. 14-25, 2021

IS/IT students will help to produce a highly competent workforce of IS/IT professionals who can not only function with minimal guidance but also contribute effectively. One of the key goals of the PM capstone course discussed in this paper is to allow IS/IT students to acquire and practice soft skills, such as problemsolving, teamwork, leadership and communication skills, in the context of managing real-world projects.

\section{Experiential Learning}

Experiential learning is an engaged learning process where students learn through experience or, more colloquially, "learn by doing" and by reflecting on the experience. It involves going through the process of actually doing the things that we want to learn and then reflecting on the experience. David A. Kolb is the person most associated with experiential learning theory. His research shows that mastering expertise is a continuous process of experience, reflection, conceptualization, and experimentation (Kolb, 2005). The experiential learning cycle is a four-step learning process (see Figure 2) that is applied multiple times in every interaction and experience.

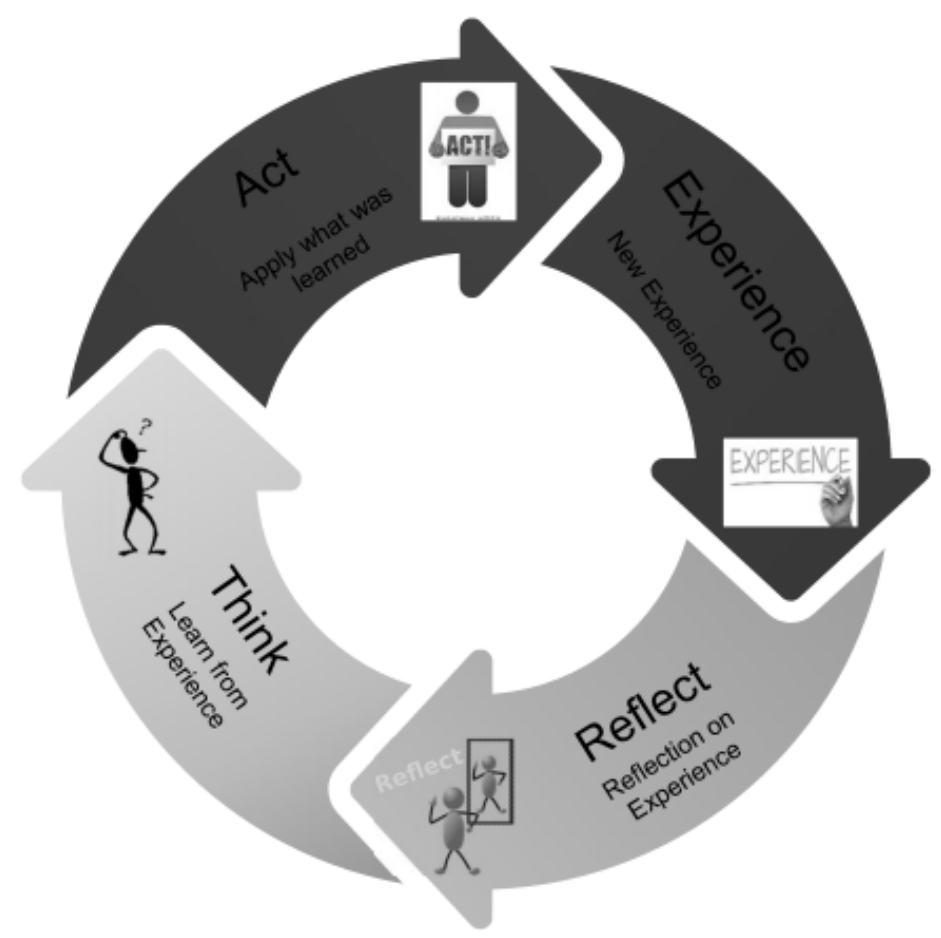

Figure 2: Kolb's 4-Step Learning Process: Experience - Reflect - Think - Act

When students are engaged in hands-on experiences followed by reflection, they are better able to connect theories and knowledge learned in the classroom to real-world situations. Experiential learning opportunities exist in a variety of forms and include experiences such as internships, student teaching, and capstone projects. The goal of a capstone project is to encourage students to think critically, solve challenging real-world problems, and develop soft skills such as communication, teamwork, and leadership. 


\section{Issues in Information Systems}

Volume 22, Issue 3, pp. 14-25, 2021

Capstone projects create self-learning opportunities and instill in students a desire to grow. These projects typically push students to apply classroom learning, life-long learning, analytical decision-making, and critical thinking to address real-world problems within real constraints. As part of the process, students perform research, set project goals, take steps along the way that are both successful and unsuccessful, make adjustments to plans, and reflect on the entire experience. As such, a capstone project checks all of the requirements of experiential learning (Hixon et al., 2012).

Benjamin Franklin is often quoted as saying: "Tell me and I forget. Teach me and I remember. Involve me and I learn." Learning by doing improves the learning process. It allows students to learn project management by actively doing instead of merely listening. Prior to taking the capstone course, students are required to take a PM fundamental course where they learn the components of the typical PM system as well as the processes and knowledge areas that are considered essential for the success of any project. Taking the capstone course allows them to practice learned concepts in a safe, controlled environment as they gain actual project management experience. This kind of experiential climate is essential to cultivating good decision-making skills.

\section{Description of the PM capstone course}

The PM capstone course we designed for the IST students at our university requires them to develop a solution to a real problem or actual need of an organization while demonstrating their mastery of PM concepts. In this section of the paper, we describe the framework of the course, the pedagogical process used, the methods applied in the life cycle of the projects (initiating, designing a solution, implementation, closing), and the overall learning experience.

Since our PM capstone projects are focused on IS/IT, students have the opportunity to plan, manage and execute a technical solution within the course's timeframe. While some institutions put the burden on students to find their own capstone projects, this is not a realistic approach for students with little or no work experience, as is the case with the students at our university. Therefore, we source real-world projects for the capstone course from local partners, which provides students with the experience of working with external sponsors who expect an outcome from the project. Prior to the start of the semester in which the capstone class is offered, IST faculty recruits capstone project sponsors. If a project idea fits the course parameters, a high-level scope is agreed upon, but it is not shared with the students.

Students are assigned to project teams with a minimum of two to a maximum of four members. Students are assigned to teams by faculty based on their interest or technical skills. In making team assignments, the goal of faculty is to provide teams with the greatest opportunity for success. Each team is assigned an external project sponsor who has identified a real IS problem that requires a solution. The students meet with faculty weekly to discuss issues and progress during the course. While a student may seek faculty advice, all activities and work products for the project are carried out by the students. At the end of the course, each team prepares a final presentation for delivery to the class and participates in a formal lessons learned session. Project sponsors are invited to attend these final presentations.

Where practical and in the interest of creating teachable moments, roadblocks may be added to a project to demonstrate a point. For example, a request may be made for a change to a requirement late in the planning phase for the express purpose of compelling rework, requiring students to implement a change control process and forcing them to negotiate with their stakeholders. 


\section{Issues in Information Systems}

Volume 22, Issue 3, pp. 14-25, 2021

\section{Course Objectives}

The articulated objective of the PM capstone course is for students to develop skills in the following project processes:

1. Initiating a project: define and authorize a project or new project phase.

2. Planning a project: establish the scope, refine objectives and define a plan to ensure that the project addresses the organization's needs.

3. Executing a project: complete the work of the project defined in the project plan.

4. Monitoring and controlling a project: track the performance of the project and initiate change when necessary.

5. Closing a project: formalize acceptance of the project and finalize closing of the project.

All projects entail significant elements of the five process groups outlined above. Since project managers must employ a wide range of activities and actions to achieve the overall goals of the project, students need to be exposed to these concepts. Furthermore, to be effective IS/IT project managers, they need to be competent in all of these areas.

\section{Course Outcomes}

Within the pedagogical framework of the PM capstone course, student teams negotiate the project scope with their project sponsor, implement a plan, and execute and document a solution meeting the sponsor's need. The final deliverable includes a service concept, a product prototype or a new process, which must reflect the acceptance criteria outlined while discussing the final scope of the project. The capstone project experience strengthens students' existing base of subject knowledge. By managing a project from initiation to closure, students:

- develop teamwork skills and learn to resolve conflict with others using negotiation techniques and patience;

- gain experience negotiating project scope, timeline, resources, and acceptance criteria;

- cultivate leadership and a sense of ownership through problem-solving;

- test their requirement-gathering skills and learn to ask open-ended, close-ended and probing questions that enhance effective requirements gathering;

- learn to cope professionally with actual real-world applications;

- improve communication skills by reflecting on the results of each project task, developing documentation, and presenting research and updates;

- appreciate how to operate with incomplete information, which is a far too common an occurrence in real-world situations.

\section{Roles and Responsibilities}

Faculty lead the capstone class and provide whatever advice the students seek with respect to their specific projects. They work with students throughout the capstone project lifecycle and continually monitor students' progress on their projects. Project sponsors ensure that the projects are consistent with their business needs. Below are some of the identified responsibilities assigned to the three principal stakeholders. 


\section{Issues in Information Systems}

Volume 22, Issue 3, pp. 14-25, 2021

Students are responsible for:

1. Consulting with faculty member(s) of their choosing (e.g., project advisors, subject matter experts), regarding various aspects of the project.

2. Developing a project plan, in consultation with their project team and sponsor, that defines the scope and schedule of the project and satisfies the requirements for the capstone class.

3. Developing the project collaboratively with their team members.

4. Communicating clearly with team members regarding their assigned work and seeking help from team members as required.

5. Managing their time and not waiting until the last minute to complete assignments/tasks.

6. Delegating responsibilities and coordinating efforts within the team.

7. Showing progress continuously throughout the life cycle of the project.

8. Delivering a presentation that provides an overview of the project and its final status.

9. Participating in a lessons learned session with classmates, sponsors and invited faculty members.

After completing the project, most students are proud of their efforts and appreciate the help of their teammates with bringing their project to a successful close. They now have tangible experience that they can put on their resumés and that will help them in beginning their careers. Additionally, students participating in these projects have the opportunity to be mentored by industry experts and are able to experience results similar to what they will encounter when they begin their professional careers.

Faculty are responsible for:

1. Ensuring that the projects selected are sufficiently complex, relevant to the student's area of specialization, have academic relevance, and will produce learning outcomes appropriate to the program.

2. Reviewing that the project selected is feasible within the timeframe allotted.

3. Providing structure and guidance to help students refine the project goals and outcomes as needed.

4. Identifying and providing any help required to have a good start on the project (i.e., a kickoff meeting).

5. Consulting with the project sponsor with regard to all issues, including those related to project goals, access to data, confidentiality, and project details.

6. Developing a clear assessment system with minimal ambiguity.

7. Monitoring the students' progress on a weekly basis to ensure a successful capstone experience.

8. Alerting students to common pitfalls, such as underestimating the time required to complete tasks or coordinating meetings with multiple stakeholders.

9. Encouraging students to assess their own strengths and weaknesses (e.g., tendency to procrastinate, openness to criticism, strong oral communication skills).

10. Ensuring that the project outcome meets the requirements specified in the description and guidelines.

11. Facilitating the lessons learned session after all projects are closed at the end of the semester.

Faculty for the course function more as guides than as instructors. They are not there to provide students with solutions to problems or to give explicit directions on what to do. Their role is to help students refine the scope of their project, develop deliverables, and research technical information related to the project on their own. Essentially, the role of the faculty is to help students develop content mastery. 


\section{Issues in Information Systems}

Volume 22, Issue 3, pp. 14-25, 2021

Project sponsors are responsible for:

1. Providing a project that is based on a problem their organization wants to solve, and that will directly benefit their organization.

2. Providing a project that offers students an opportunity to work both independently and as part of a team.

3. Providing a project that can stand alone and that is not critically tied to any other project or process.

4. Meeting face-to-face (or via video conferencing) with the student team to discuss project details periodically.

5. Communicating periodically regarding the goals of the project.

6. Evaluating the feasibility of completing the project through discussions with the student team and course faculty.

The capstone project allows students to experience all of the PM process groups and most of the PM knowledge areas (Project Management Institute, 2017). By developing, negotiating, and managing their project plan, students are engaged intellectually and emotionally in the outcome. One recent project typifies the kind of experiential learning that appears to occur as a result of such engagement. For this project, students were asked to build an online contact management system for a client. Anecdotal information from both the student team and the project sponsor indicated that the project in the early stages suffered from scope creep and delays because of the team's failure to manage the sponsor's expectations. The team was able to rally and get back on track, but their early missteps taught them the value of fortifying agreements early in the project life cycle. Their mistake also became a teachable moment for the other teams in the class. The process of course correction also enabled the students to practice some of the soft skills (such as negotiating, trust-building, conflict management, problem-solving, communication, critical thinking, and leadership) that are needed in the workplace.

Table 1 below shows how some of the work product of past capstone teams maps against the PM process groups and knowledge areas. By practicing learned concepts in a safe, controlled environment, students gain project management experience. Since most of our capstone projects were unfunded, it was difficult to incorporate cost management and procurement management activities.

Table 1. Team Outputs mapped to PM Process groups and Knowledge Areas (PMBOK)

\begin{tabular}{|c|c|c|c|c|c|}
\hline \multirow{2}{*}{$\begin{array}{l}\text { Knowledge } \\
\text { Areas }\end{array}$} & \multicolumn{5}{|c|}{ Project Management Process Groups with Capstone Team Outputs } \\
\hline & Initiate & Plan & Execute & $\begin{array}{c}\text { Monitor and } \\
\text { Control }\end{array}$ & Close \\
\hline $\begin{array}{l}\text { Project } \\
\text { Integration } \\
\text { Management }\end{array}$ & $\begin{array}{l}\text { Project } \\
\text { Charter }\end{array}$ & $\begin{array}{l}\text { Project Management } \\
\text { Plan }\end{array}$ & $\begin{array}{l}\text { Practice } \\
\text { directing/managin } \\
\text { g project work }\end{array}$ & $\begin{array}{l}\text { Practice } \\
\text { monitoring and } \\
\text { controlling } \\
\text { project work } \\
\text { (i.e., change } \\
\text { request, PM } \\
\text { plan updates) }\end{array}$ & $\begin{array}{l}\text { Close } \\
\text { project }\end{array}$ \\
\hline $\begin{array}{l}\text { Project Scope } \\
\text { Management }\end{array}$ & & $\begin{array}{l}\text { Plan scope } \\
\text { management } \\
\text { requirements } \\
\text { (i.e., work breakdown } \\
\text { structure (WBS)) }\end{array}$ & & $\begin{array}{l}\text { Validate/contro } \\
1 \text { scope }\end{array}$ & \\
\hline $\begin{array}{l}\text { Project Time } \\
\text { Management }\end{array}$ & & $\begin{array}{l}\text { Plan time management } \\
\text { (i.e., estimate } \\
\text { activities/duration) }\end{array}$ & & & \\
\hline
\end{tabular}




\section{Issues in Information Systems}

Volume 22, Issue 3, pp. 14-25, 2021

\begin{tabular}{|c|c|c|c|c|}
\hline $\begin{array}{l}\text { Project Cost } \\
\text { Management }\end{array}$ & & $\begin{array}{l}\text { Plan cost management } \\
\text { budget/costs } \\
\text { (usually N/A) }\end{array}$ & & $\begin{array}{l}\text { Control cost } \\
\text { (usually N/A) }\end{array}$ \\
\hline $\begin{array}{l}\text { Project Quality } \\
\text { Management }\end{array}$ & & $\begin{array}{l}\text { Plan quality } \\
\text { management }\end{array}$ & $\begin{array}{l}\text { Practice quality } \\
\text { management }\end{array}$ & Control quality \\
\hline $\begin{array}{l}\text { Project Human } \\
\text { Resource } \\
\text { Management } \\
\end{array}$ & & Plan HR management & $\begin{array}{l}\text { Practice acquiring, } \\
\text { developing and } \\
\text { managing a team }\end{array}$ & \\
\hline $\begin{array}{l}\text { Project Risk } \\
\text { Management }\end{array}$ & & $\begin{array}{l}\text { Plan risk management } \\
\text { register }\end{array}$ & & Control risks \\
\hline $\begin{array}{l}\text { Project } \\
\text { Communication } \\
\text { Management }\end{array}$ & & $\begin{array}{l}\text { Plan communication } \\
\text { management }\end{array}$ & $\begin{array}{l}\text { Practice managing } \\
\text { communications }\end{array}$ & $\begin{array}{l}\text { Control } \\
\text { communication }\end{array}$ \\
\hline $\begin{array}{l}\text { Project } \\
\text { Procurement } \\
\text { Management }\end{array}$ & & $\begin{array}{l}\text { Plan procurement } \\
\text { management } \\
\text { (usually N/A) }\end{array}$ & $\begin{array}{l}\text { Conduct } \\
\text { procurement } \\
\text { (usually N/A) }\end{array}$ & $\begin{array}{l}\text { Control } \\
\text { procurement } \\
\text { (usually N/A) }\end{array}$ \\
\hline $\begin{array}{l}\text { Project } \\
\text { Stakeholder } \\
\text { Management }\end{array}$ & $\begin{array}{l}\text { Identify } \\
\text { stakeholder } \\
\text { (i.e., build } \\
\text { register) }\end{array}$ & $\begin{array}{l}\text { Plan stakeholder } \\
\text { management }\end{array}$ & $\begin{array}{l}\text { Practice managing } \\
\text { stakeholder } \\
\text { engagement }\end{array}$ & $\begin{array}{l}\text { Practice } \\
\text { managing } \\
\text { stakeholder } \\
\text { engagement }\end{array}$ \\
\hline
\end{tabular}

At the conclusion of the capstone course, a lessons learned session is held and the students get an opportunity to share their experiences. The entire class is required to attend this final session. IST faculty (not involved with the course), sponsors and junior IST students are invited to the event. Students discuss their projects and their specific contributions and reflect upon the experience. In addition to providing an excellent opportunity for reflection, the event serves as a mechanism for students to practice their public speaking skills. In this final session, feedback from external partners is collected, which is used to help assess whether students are learning the necessary skills needed to succeed after graduation.

\section{Conclusion/Future research}

The PM capstone experience provides students with a means of applying PM principles to a real-world situation. In this regard, it is seen as a success. The course allows students to practice their PM technical skills while helping them to develop confidence in the soft skills of teamwork, problem-solving, leadership and communication. Since they are working on real-world problems, students learn how to deal with problems that are not clearly defined. This paper documents how we set up an intensive, three-credit hour course that mirrors real-world IS/IT project engagements and leads to the effective delivery of beneficial solutions to sponsor organizations.

The informal feedback received after course completion indicates that the projects are considered to be challenging and educational. Future research in this area could evaluate ways in which the experiential learning in the PM capstone course could be enhanced through closer connections between the course and practical real-world applications. The value and benefit of the PM capstone course as a "learning by doing" pedagogical technique also can be tested and validated through survey studies of current students, alumni, faculty, and sponsor organizations who have been involved with the course. Survey data is also a useful tool for improving the course as it currently exists. Finally, future research could focus on the quantitative and qualitative results and experiences of the students and/or the capstone sponsors, and also assess the value of the projects, best practices, and lessons learned based on their successful delivery.

In summary, the use of real-world projects in a PM capstone course provides IS/IT students with the opportunity to demonstrate and apply textbook PM knowledge in a real-world setting. As they practice their 


\section{Issues in Information Systems}

Volume 22, Issue 3, pp. 14-25, 2021

PM hard skills to produce read-world solutions to business problems, students also necessarily develop essential soft skills. Although the capstone course requires significant effort on the part of all stakeholders (faculty, students, and sponsors) and carries some risks due to unknowns and uncontrollable events, it provides a unique experience that results in satisfied sponsors in the short term and ultimately leads to wellrounded industry professionals in the long term.

\section{References}

Bohler, J. A., Larson, B., Peachey, T. A., \& Shehane, R. F. (2020). Evaluation of Information Systems Curricula. Journal of Information Systems Education, 31(3), 232-243.

Bolton, R. (1986), People Skills, Touchstone Books, New York, NY

Crawford, J. K. (2006). Why project managers fail—and how to help them succeed! Paper presented at PMI ${ }^{\circledR}$ Global Congress 2006-North America, Seattle, WA. Newtown Square, PA: Project Management Institute.

Dunlap, J. (2005). Problem-Based Learning and Self-Efficacy: How a Capstone Course Prepares Students for a Profession. Educational Technology Research and Development, 53(1), 65-85.

Gray, Kevin. (2021, April 19). The Attributes Employers Seek on Students' Resumes. Retrieved from NACE - National Association of College and Employers: https://www.naceweb.org/talentacquisition/candidate-selection/the-attributes-employers-seek-on-students-resumes/

Hixson, C. A., Paretti, M. C., Pembridge, J. J. (2012, June), Capstone Design Faculty Motivation: Motivational Factors for Teaching the Capstone Design Course and Motivational Influences on Teaching Approaches Paper presented at 2012 ASEE Annual Conference; Exposition, San Antonio, Texas. 10.18260/1-2--21041

Kolb, A., and Kolb, D. A., 2005, Learning styles and learning spaces: Enhancing experiential learning in higher education, Academy of Management Learning and Education, v. 4. n. 2, p. 193-212.

Konrad, Renata \& Hall-Phillips, Adrienne \& Vila-Parrish, Anita. (2018). Are Our Students Prepared? The Impact of Capstone Design Pedagogical Approaches on Student Skill Development During Industry-Sponsored Fieldwork. INFORMS Transactions on Education. 18. 10.1287/ited.2018.0198.

Kumar, V. S. (2009). Essential leadership skills for project managers. Paper presented at PMI® Global Congress 2009-North America, Orlando, FL. Newtown Square, PA: Project Management Institute.

Leidig, P., Salmela, H., Anderson, G., Babb, J., Gardner, L., Nunamaker, J., Scholtz, B., Shankararaman, V., Sooriamurthi, R., Thouin, M., Villiers, C., IS 2020: Developing an ACM/AIS Information Systems Model Curriculum for Undergraduate Programs. AMCIS 2020, Aug 2020, Salt Lake City, Utah.

Leonard, L., Jones, K., \& Lang, G. (2019). Information Systems Curriculum versus Employer Needs: A Gap Analysis. Information Systems Education Journal, 17(5), 32-38. 


\section{Issues in Information Systems}

Volume 22, Issue 3, pp. 14-25, 2021

Longenecker, H.E., Babb, J., Waguespack, L.J., Janicki, T.N., Feinstein, D. L. (2015). Establishing the Basis for a CIS (Computer Information Systems) Undergraduate Program: On Seeking the Body of Knowledge, ISEDJ Volume 13, No. 5, September 2015 Marques, J. (2013). Understanding the Strength of Gentleness: Soft-Skilled Leadership on the Rise. Journal of Business Ethics, 116(1), 163-171.

Marques, J. (2013) Understanding the Strength of Gentleness: Soft-Skilled Leadership on the Rise. Journal of Business Ethics, 116(1): 163-171.

Matturro, Gerardo \& Raschetti, F. \& Fontán, C.. (2019). A systematic mapping study on soft skills in software engineering. Journal of Universal Computer Science. 25. 16-41.

National Association of Colleges and Employers (NACE)., (2020, January 13). Key attributes employers want to see on resumes. https://www.naceweb.org/talent-acquisition/candidate-selection/keyattributes-employers-want-to-see-on-students-resumes/

Project Management Institute. (2017). A guide to the Project Management Body of Knowledge (PMBOK guide) (6th ed.). Project Management Institute. Newton Square, PA, USA: PMI.

Schulz, B. (2008). The importance of soft skills: Education beyond academic knowledge. NAWA Journal of Language \& Communication, 2(1).

Schwalbe, K. (2019). Information Technology Project Management, 9th ed. US: Cengage.

Sukhoo, A., Barnard, A., Eloff, M., Van der Poll, J., \& Motah, M. (2005). Accommodating Soft Skills in Software Project Management. Issues in Informing Science and Information Technology. 2. 691703. $10.28945 / 860$.

Tabatabaei, Manouchehr \& Reichgelt, Han, (2005). The Effect of Prior Exposure to Project Management Techniques in Project-Based Courses, Journal of Issues in Information Systems, VI(1), 2005, 398-403.

Task Force on PM Curricula (2017), PM Curriculum and Resources. Newton Square, PA: Project Management Institute. [Online] Available: http://pmiteach.org

Topi, H., Valacich, J. S., Wright, R. T., Kaiser, K. M., Nunamaker Jr., J. F., Sipior, J. C., \& de Vreede, G. J. (2010). 2010 Curriculum Guidelines for Undergraduate Degree Programs in Information Systems.

Troukens, K. (2013). Sharpen your soft skills in this workshop of underestimated project management tools. Paper presented at PMI ${ }^{\circledR}$ Global Congress 2013-North America, New Orleans, LA. Newtown Square, PA: Project Management Institute. 